\title{
PENGARUH MACAM PUPUK MAJEMUK DAN JUMLAH BIBIT PERLUBANG TERHADAP FASE VEGETATIF TANAMAN PADI (Oryza sativa L.)
}

\section{THE EFFECT OF KINDS OF FERTILIZER AND NUMBER OF SEEDS FOR PERFORMANCE ON VEGETATIVE PHASE OF RICE PLANT (Oryza sativa L.)}

\author{
Dinnul Mubarok, Mariyatul Qibtiyah, Muhammad Imam Aminuddin \\ Program Studi Agroteknologi Fakultas Pertanian \\ Universitas Islam Darul ‘Ulum Lamongan \\ Korespondensi : mubarok11dinnul@gmail.com, mariyatulqibtiyah@unisda.ac.id, \\ imamaminuddin@unisda.ac.id
}

\begin{abstract}
ABSTRAK
Tanaman padi adalah tanaman pangan pokok di Indonesia dengan tingkat produksi dan konsumsi yang tinggi. Padi menghasilkan beras sebagai makanan pokok masyarakat di Kabupaten Lamongan khususnya dan masyarakat Indonesia pada umumnya. Strategi yang ditempuh dalam rangka peningkatan pertumbuhan dan produksi tanaman padi adalah penggunaan pupuk majemuk dan jumlah bibit perlubang. penelitian ini bertujuan untuk mengetahui pengaruh pupuk majemuk dan jumlah bibit perlubang terhadap fase vegetatif tanaman padi. Penelitian ini dilakukan di Desa Kesambi, Kecamatan Pucuk, Kabupaten Lamongan. Waktu penelitian dimulai bulan April sampai Juni 2020. Penelitian ini menggunakan metode rancangan acak kelompok (RAK) yang disusun secara faktorial dengan dua faktor perlakuan yaitu Macam Pupuk dan Jumlah Bibit Perlubang. Faktor Macam Pupuk Terdiri dari 3 level yaitu: Tanpa pupuk, Pupuk Phonska, dan Pupuk Mutiara. Faktor jumlah Bibit Perlubang terdiri dari 3 level yaitu : 2 Bibit, 3 Bibit, dan 5 Bibit. Hasil penelitian menunjukkan bahwa adanya interaksi antara perlakuan pupuk mutiara dan 3 bibit perlubang. Kombinasi perlakuan terbaik adalah pupuk mutiara dan 3 bibit perlubang terhadap parameter tinggi tanaman dan jumlah anakan.
\end{abstract}

Kata kunci : jumlah bibit, padi, pupuk majemuk.

\section{ABSTRACT}

The rice plant is a staple food crop in Indonesia with high levels of production and consumption . Rice produces rice as a staple food for the people in Lamongan Regency in particular and Indonesian people in general. The strategy taken in order to increase the growth and production of rice plants is the use of compound fertilizers and the number of seeds per hole. This study aims to determine the effect of compound fertilizers and the number of seeds per hole on the vegetative phase of rice plants. This research was conducted in Kesambi Village, Pucuk District, Lamongan Regency. The research period starts from April to June 2020. This study used a randomized block design (RAK) which was arranged factually with two treatment factors, namely the Kind of Fertilizer and the Number of Perforated Seeds. Fertilizer Kinds Factors Consists of 3 levels, namely: No fertilizer, Phonska Fertilizer, and Pearl Fertilizer. The number of perforated seeds consists of 3 levels, namely: 2 seeds, 3 seeds, and 5 seeds. The results showed that there was an interaction between pearl fertilizer treatment and 3 perforated seeds. The best treatment combination is pearl fertilizer and 3 perforated seeds on the parameters of plant height and number of tillers.

Key words: number of seeds, rice, compound fertilizer. 


\section{PENDAHULUAN}

Tanaman padi (Oryza sativa L.) adalah tanaman pangan pokok di Indonesia dengan tingkat produksi dan konsumsi yang tinggi. penduduk indonesia $90 \%$ menggunakan beras untuk makanan pokok karena beras mengandung $\quad 40-80 \%$ kalori dan $45-55 \%$ protein. Sumbangan beras untuk memenuhi kebutuhan gizi tersebut makin besar pada lapisan penduduk ekonomi rendah (Koswara, 2009).

Menurut BPS Lamongan (2019) Penggunaan lahan di Kabupaten Lamongan, khususnya pada luas lahan sawah menurut jenis pengairannya yaitu irigasi dan non irigasi. Total luas areal persawahan dengan jenis pengairan irigasi pada tahun 2018 adalah 53.243 ha, sedangkan jenis pengairan non irigasi digunakan pada lahan sawah dengan seluas 34.590 ha. Pada tahun 2018 Kabupaten Lamongan dapat menghasilkan padi sebesar 1.053.796 ton/ha.

Pemakaian jumlah bibit padi per titik tanam dapat berpengaruh terhadap pertumbuhan. Pemakaian bibit dalam jumlah banyak (5-10 batang per titik tanam), karena dapat menyebabkan terjadinya persaingan antara tanaman padi untuk menyerap air, unsur hara, $\mathrm{CO}_{2}, \mathrm{O}_{2}$, cahaya, maupun ruang untuk tumbuh, sehingga pertumbuhan tanaman tidak normal, tanaman rentan penyakit, dan mengurangi hasil produksi gabah (Abdullah, 2004).

Rekomendasi untuk pemakaian jumlah bibit padi sawah yaitu 1-3 batang per titik tanam. Pada sistem SRI (The System of Rice Intensification) jumlah bibit yang diterapkan yaitu 1 batang per lubang tanam, karena dapat menghindari kompetisi pada tanaman untuk menyerap unsur hara dan dapat meminimal biaya produksi karena bibit yang digunakan lebih sedikit (Kasim, 2004).

Pupuk majemuk (NPK) adalah pupuk anorganik yang digunakan untuk memenuhi kebutuhan nutrisi hara makro (N, P, dan $\mathrm{K}$ ). kombinasi perlakuan tersebut diulang 3 kali sehingga diperoleh 27 sampel percobaan.
Pupuk anorganik merupakan pupuk yang diproduksi dari bahan kimia. Penelitian ini menggunakan pupuk mutiara (NPK) dan pupuk Phonska. NPK Phonska adalah pupuk kima yang mengandung nitrogen (N) $15 \%$, Fosfor $\left(\mathrm{P}_{2} \mathrm{O}_{5}\right) 15 \%$, Kalium $\left(\mathrm{K}_{2} \mathrm{O}\right) 15 \%$, Sulfur (S) $10 \%$, dan kadar air maksimal $2 \%$. Pupuk NPK Mutiara adalah pupuk yang mengandung $16 \% \mathrm{~N}$ (Nitrogen), 16\% $\mathrm{P}_{2} \mathrm{O}_{5}$ (Phospate), 16\% $\mathrm{K}_{2} \mathrm{O}$ (Kalium), 0.5\% MgO (Magnesium), dan 6\% $\mathrm{CaO}$ (Kalsium). Pupuk NPK mutiara memiliki kelebihan dibanding pupuk NPK lainnya. Pupuk mutiara mudah larut dalam air, sehingga unsur yang terdapat di dalam pupuk dapat terserap secara efektif (Kaya, 2013).

Tujuan dari penelitian ini untuk mengetahui pengaruh aplikasi macam pupuk majemuk dan jumlah bibit perlubang terhadap fase vegetatif tanaman padi.

\section{Waktu dan Tempat}

\section{BAHAN DAN METODE}

Penelitian ini dilakukan di Desa Kesambi, Kecamatan Pucuk, Kabupaten Lamongan. Penelitian ini dimulai pada bulan April sampai Juni 2020 dengan curah hujan 1.585 setiap tahunya.

\section{Bahan dan Alat}

Alat yang digunakan adalah cangkul, sabit, pisau, semprotan, meteran, gunting, alat-alat tulis, papan nama, dan penunjang lainnya. Bahan yang digunakan meliputi benih padi varietas inpari 32, pupuk phonska, pupuk NPK mutiara, pupuk urea, pupuk organik, dan pestisida pengendali hama dan penyakit

\section{Metode Penelitian}

Rancangan yang digunakan adalah rancangan acak kelompok (RAK) menggunakan dua faktor perlakuan yaitu: Faktor I : Macam pupuk majemuk $(\mathrm{P})$ dengan 3 level : $\mathrm{PO}=$ Kontrol, P1 = Phonska, P2 = Mutiara.Faktor II : Jumlah bibit perlubang ( $\mathrm{B}$ ) dengan 3 leve I: B1 = 2 Bibit, $\quad$ B2 $=3$ Bibit, B3 = 5 Bibit Dari kedua faktor tersebut, diperoleh 9 kombinasi perlakuan dan 3 kali ulangan. Masing-masing

\section{Pelaksanaan Penelitian Pengolahan Tanah}

Pengolahan tanah diawali dengan pembersihan gulma yang ada di lahan. Selanjutnya dilakukan pembalikan atau penggemburan tanah dengan cara 
pembajakan atau mencangkul agar mudah untuk ditanami.

Pengolahan Lahan Budidaya

Pengolahan lahan budidaya lakukan dengan pembersihan lahan, pembajakan tanah, dan pencangkulan. Setelah itu dilakukan pembuatan petakan dengan ukuran $2 \mathrm{~m}$ persegi sebanyak 27 petakan dan dibuatkan saluran air sekaligus sebagai pembatas antar petak dan ulangan.

\section{Penanaman}

Penanaman dilakukan langsung dengan kondisi air macak-macak. Penanaman dengan posisi bibit tegak dengan jumlah tanaman satu lubang 3 bibit/rumpun dengan tanaman yang sesuai dengan perlakuan.

\section{Pemeliharaan}

Kegiatan pemeliharaan padi yaitui pengendalian organisme pengganggu tanaman dilakukan apabila tanaman terserang penyakit. pemupukan dilakukan ketika padi berumur 7 hari dan 25 hari setelah tanam. Pengairan dilakukan pada saat tanaman padi membutuhkan atau kelebihan air. Penyiangan dilakukan ketika gulma tumbuh disekitar tanaman budidaya.

\section{Pengamatan}

Pengamatan dilakukan setiap 14 hari sekali.

Setiap petak diambil 5 tanaman sebagai tanaman sampel . pengamatan yang dilakukan adalah pengamatan fase vegetatif dan fase generatif.

\section{Pengamatan Fase Vegetatif:}

- Tinggi tanaman $(\mathrm{cm})$

Pertumbuhan tinggi tanaman diukur tinggi tanaman pada fase vegetatif mulai pangkal tanaman sampai ujung daun tertinggi.

- Jumlah Anakan

Pertumbuhan jumlah anakan dihitung berdasarkan jumlah tunas yang tumbuh pada saat fase vegetatif.

\section{Pengamatan Fase Generatif:}

- Jumlah Malai

Menghitung malai dari tanaman sampel dengan menghitung semua malai yang ada dalam serumpun. Perhitungan malai dilakukan pada tanaman sampel waktu panen.

\section{Analisis}

Data hasil setiap parameter pengamatan dianalisa menggunakan uji Fhisher (uji F) 5\% dan $1 \%$ apabila terdapat perbedaan nyata dilanjutkan dengan uji Beda Nyata Terkecil (BNT 5\%).

\section{HASIL DAN PEMBAHASAN}

\section{Tinggi Tanaman}

Hasil sidik ragam menunjukkan bahwa adanya interaksi antara perlakuan jumlah 3 bibit perlubang dan pupuk mutiara terhadap tinggi tanaman pada umur 28 hst dan 42 hst .

Tabel 3. Rerata Tinggi Tanaman (cm) pada Pengamatan Umur 28 hst dan 42 hst

\begin{tabular}{lcc}
\hline \multirow{2}{*}{ Perlakuan } & \multicolumn{2}{c}{ Rerata Tinggi Tanaman $(\mathrm{cm})$ pada Pengamatan Umur ke } \\
\cline { 2 - 3 } & $28 \mathrm{hst}$ & $42 \mathrm{hst}$ \\
\hline Kontrol + 2 bibit & $48,07 \mathrm{c}$ & $59,87 \mathrm{c}$ \\
Kontrol + Bibit 3 & $47,17 \mathrm{~d}$ & $61,23 \mathrm{bc}$ \\
Kontrol + Bibit 5 & $47,63 \mathrm{~d}$ & $60,47 \mathrm{c}$ \\
Phonska + Bibit 2 & $47,23 \mathrm{~d}$ & $61,13 \mathrm{~b}$ \\
Phonska + Bibit 3 & $50,10 \mathrm{~b}$ & $60,60 \mathrm{c}$ \\
Phonska + Bibit 5 & $50,00 \mathrm{~b}$ & $62,80 \mathrm{~b}$ \\
Mutiara + Bibit 2 & $50,37 \mathrm{~b}$ & $62,83 \mathrm{~b}$ \\
Mutiara + Bibit 3 & $53,07 \mathrm{a}$ & $64,37 \mathrm{a}$ \\
Mutiara + Bibit 5 & $50,97 \mathrm{~b}$ & $61,97 \mathrm{~b}$ \\
\hline BNT 5\% & 1,97 & 1,87 \\
\hline
\end{tabular}

Keterangan : Angka-angka yang diikuti oleh huruf yang sama dalam kolom yang sama tidak berbeda nyata dengan uji BNT 5\%. 
Pada tabel 3, dapat dilihat bahwa pengamatan parameter tinggi tanaman menunjukkan kombinasi perlakuan jumlah 3 bibit perlubang dan pupuk mutiara dengan terbaik terdapat pada perlakuan jumlah 3 bibit perlubang dan pupuk mutiara dengan nilai $64,37 \mathrm{~cm}$ pada pengamatan umur $28 \mathrm{hst}$ dan 42 hst.

Menurut Atman (2007) bahwa penggunaan bibit Pemakaian bibit yang lebih banyak dapat menyebabkan terjadinya persaingan antara tanaman padi untuk menyerap air, unsur hara, $\mathrm{CO}_{2}, \mathrm{O}_{2}$, cahaya, maupun ruang untuk tumbuh, sehingga pertumbuhan tanaman tidak normal. Akibatnya, pertumbuhan tanaman tidak normal, tanaman rentan penyakit, dan mengurangi hasil produksi gabah. Apabila pemakaian bibit yang sedikit (1-3 bibit per lubang tanam) dapat mengurangi persaingan antara tanaman padi akan ringan, penggunaan jumlah benih yang sedikit dapat mengurangi biaya produksi dan hasil produksi gabah meningkat.

Menurut Munandar (2013) bahwa Penggunaan pupuk secara lengkap dan tepat sesuai kebutuhan tanaman yang mengandung $\mathrm{N}$ (Nitrogen), $\mathrm{P}_{2} \mathrm{O}_{5}$ (Fosfor), $\mathrm{K}_{2} \mathrm{O}$ (Kalium), MgO (Magnesium), dan $\mathrm{CaO}$ (Kalsium), dapat memberikan kontribusi untuk memenuhi kebutuhan nutrisi tanaman yang dibutuhkan. Sehingga kebutuhan tanaman dapat terpenuhi, akibatnya tanaman dapat tumbuh tinggi dan berkembang secara baik. Gardner, Dkk. (1991) menyatakan unsur hara $\mathrm{N}$ memiliki fungsi sebagai bahan penyusun asam amino dan untuk pembelahan, pembesaran sel sehingga sangat berdampak pada pertumbuhan tinggi tanaman.

\section{Jumlah Anakan}

Hasil sidik ragam menunjukkan bahwa adanya interaksi antara perlakuan jumlah 3 bibit perlubang dan pupuk mutiara terhadap jumlah anakan pada umur 28 hst dan 42 hst.

Tabel 4. Rerata Jumlah Anakan pada Pengamatan Umur 28 hst dan 42 hst.

\begin{tabular}{lcc}
\hline \multirow{2}{*}{ Perlakuan } & \multicolumn{2}{c}{ Rerata Jumlah anakan pada Pengamatan Umur ke } \\
\cline { 2 - 3 } & 28 hst & 42 hst \\
\hline Kontrol + 2 bibit & $19,13 \mathrm{c}$ & $28,00 \mathrm{~d}$ \\
Kontrol + Bibit 3 & $19,90 \mathrm{bc}$ & $29,23 \mathrm{~cd}$ \\
Kontrol + Bibit 5 & $18,87 \mathrm{c}$ & $26,67 \mathrm{~d}$ \\
Phonska + Bibit 2 & $20,63 \mathrm{bc}$ & $29,83 \mathrm{c}$ \\
Phonska + Bibit 3 & $21,77 \mathrm{~b}$ & $31,87 \mathrm{~b}$ \\
Phonska + Bibit 5 & $20,30 \mathrm{bc}$ & $29,53 \mathrm{c}$ \\
Mutiara + Bibit 2 & $21,93 \mathrm{~b}$ & $34,00 \mathrm{~b}$ \\
Mutiara + Bibit 3 & $26,57 \mathrm{a}$ & $38,43 \mathrm{a}$ \\
Mutiara + Bibit 5 & $21,67 \mathrm{~b}$ & $33,07 \mathrm{~b}$ \\
\hline BNT 5\% & 1,88 & 1,34 \\
\hline
\end{tabular}

Keterangan: Angka-angka yang diikuti oleh huruf yang sama dalam kolom yang sama tidak berbeda nyata dengan uji BNT 5\%.

Pada tabel 4, dapat dilihat bahwa pengamatan parameter jumlah anakan menunjukkan kombinasi perlakuan 3 jumlah bibit perlubang dan pupuk mutiara dengan terbaik terdapat pada perlakuan jumlah 3 bibit perlubang dan pupuk mutiara dengan jumlah 38,43 anakan pada pengamatan umur 28 hst dan 42 hst.

Menurut Dachban dan Dibisono (2010), banyaknya jumlah bibit per titik tanam menyebabkan terjadinya persaingan tanaman, persaingan terjadi pada tanaman dalam satu rumpun ataupun antara Laju tumbuh tanaman (LTT). Akibatnya, kondisi suatu tanaman dalam tingkat produksi bahan kering pertanaman yang akan mengalami penurunan, sehingga tingkat distribusinya dari daun ke tangkai bunga dan akhirnya sampai kepembentukan biji. Hasil penelitian Susilo dkk, (2015), menyebutkan bahwa jumlah 
anakan produktif dipengaruhi oleh faktor jumlah bibit per lubang tanam.

Penggunaan pupuk secara lengkap dan efisien sesuai dengan yang dibutuhkan tanaman yang mengandung $\mathrm{N}$ (Nitrogen), $\mathrm{P}_{2} \mathrm{O}_{5}$ (Fosfor), $\mathrm{K}_{2} \mathrm{O}$ (Kalium) $\mathrm{MgO}$ (Magnesium), dan $\mathrm{CaO}$ (Kalsium), dapat memberikan kontribusi untuk memenuhi kebutuhan nutrisi yang diperlukan oleh tanaman. Sehingga kebutuhan tanaman dapat terpenuhi, tanaman dapat tumbuh tinggi dan berkembang secara baik (Munandar, 2013).

Hasil sidik ragam menunjukkan bahwa pengamatan parameter jumlah anakan menunjukkan adanya pengaruh perbedaan nyata pada perlakuan macam pupuk umur 14 hst.

Tabel 5. Rerata Jumlah Anakan Pada Umur 14 hst.

\begin{tabular}{cc}
\hline Perlakuan & Rerata jumlah anakan umur 14 hst \\
\hline Kontrol & $7,87 \mathrm{~b}$ \\
Phonska & $7,60 \mathrm{~b}$ \\
Mutiara & $8,93 \mathrm{a}$ \\
\hline BNT 5\% & 0,94 \\
\hline
\end{tabular}

Keterangan: Angka-angka yang diikuti oleh huruf yang sama dalam kolom yang sama tidak berbeda nyata dengan uji BNT 5\%.

Pada tabel 5, menunjukkan bahwa hasil terbaik ditunjukkan pada perlakuan pupuk mutiara . Pengamatan jumlah anakan menunjukkan pengaruh perbedaan nyata pada perlakuan pemberian pupuk. Pada perlakuan pupuk mutiara menunjukan terdapat hasil berbeda nyata dengan yang lain dengan notasi a. Sedangkan pada perlakuan pupuk phonska dan tanpa pupuk atau kontrol terdapat hasil yang menunjukan tidak beda nyata dengan notasi yang sama. Hal ini diduga karena kandungan pupuk mutiara yang cukup lengkap sehingga mampu membantu daya tumbuh dan perkembangan tanaman.

\section{Jumlah Malai}

Hasil sidik ragam menunjukkan bahwa pengamatan parameter jumlah malai menunjukkan adanya perbedaan nyata pada

Tabel 6. Rerata Jumlah Malai

\begin{tabular}{cc}
\hline Perlakuan & Rerata jumlah malai umur 58 \\
\hline Kontrol & $58,20 \mathrm{~b}$ \\
Phonska & $59,17 \mathrm{~b}$ \\
Mutiara & $60,13 \mathrm{a}$ \\
\hline BNT 5\% & 0,94 \\
\hline
\end{tabular}

Keterangan: Angka-angka yang diikuti oleh huruf yang sama dalam kolom yang sama tidak berbeda nyata dengan uji BNT 5\%.

Pada tabel 6, menunjukkan bahwa pupuk mutiara berbeda nyata dengan perlakuan kontrol dan pupuk phonska hasil terbaik ditunjukkan pada perlakuan pupuk
Pupuk NPK Mutiara adalah pupuk yang mengandung $16 \% \mathrm{~N}$ (Nitrogen), $16 \%$ $\mathrm{P}_{2} \mathrm{O}_{5}$ (Phospate), $16 \% \mathrm{~K}_{2} \mathrm{O}$ (Kalium), $0.5 \% \mathrm{MgO}$ (Magnesium), dan 6\% $\mathrm{CaO}$ (Kalsium). Pupuk NPK mutiara menyediakan kebutuhan nutrisi yang dibutuhkan tanaman. Sehingga kebutuhan tanaman dapat terpenuhi, pada akhirnya tanaman dapat tumbuh tinggi dan berkembang secara baik (Munandar, 2013).

perlakuan macam pupuk terhadap jumah malai. mutiara. Pengamatan jumlah malai menunjukkan pengaruh perbedaan nyata pada perlakuan pemberian pupuk. Pada perlakuan pupuk mutiara menunjukan 
terdapat hasil berbeda nyata dengan yang lain dengan notasi a. Sedangkan pada perlakuan pupuk phonska dan tanpa pupuk atau kontrol terdapat hasil tidak beda nyata ditunjukkan dengan notasi yang sama. Hal ini diduga karena kandungan pupuk mutiara yang cukup lengkap sehingga mampu membantu daya tumbuh dan perkembangan tanaman terhadap fase vegetatif dan generatif.

Yitnosumarto (1993), menjelaskan bahwa penggunaan pupuk dengan tingkat optimal untuk tanaman yang dilakukan secara terus menerus akan menaikan kapasitas produktif tanah sehingga dapat meningkatkan produksi tanaman, karenakan pupuk NPK Mutiara mengandung unsur hara $\mathrm{N}, \mathrm{P}, \mathrm{K}$ yang disesuaikan dengan manfaatnya yaitu unsur Nitrogen (N) berfungsi untuk memicu pertumbuhan secara umum, terutama pada fase vegetatif yang berperan dalam pembentukan klorofil, asam amino, enzim dan persenyawa lain. Fospor ( $P$ ) berfungsi sebagai pembentukan protein dan mineral yang penting untuk tanaman, dan dapat merangsang pertumbuhan akar. Unsur hara kalium (K) berfungsi untuk menghasilkan protein karbonhidrat dan gula, memperkuat jaringan tanaman dan meningkatkan daya tahan penyakit.

Produksi tanaman padi ditunjukan oleh jumlah malai pada setiap rumpun ataupun per satuan luas dan kepadatan malai. Umumnya pada fase vegetatif dapat menentukan jumlah malai per rumpun, masa vegetatif yang akan mengakibatkan bertambahnya anakan yang terbentuk, tetapi presentasi anakan yang menghasilkan malai cenderung akan turun pula. Hal ini disebabkan faktor kesuburan tanah dan pemakaian pupuk yang dapat mempengaruhi jumlah anakan yang menghasilkan malai. Jumlah bulir dalam satu malai tergantung pada kegiatan selama fase reproduksi. Kegiatan fotosintesis pada saat ini sangat mempengaruhi jumlah gabah atau malai (Sutorodkk, 2015).

\section{KESIMPULAN}

Dari hasil penelitian yang telah dilakukan pada macam pupuk majemuk dan jumlah bibit perlubang terhadap fase vegetatif tanaman padi dapat disimpulkan bahwa :
1. Menunjukkan adanya interaksi antara perlakuan pupuk mutiara dan 3 bibit perlubang pada parameter jumlah anakan dan tinggi tanaman.

2. Kombinasi perlakuan penggunaan pupuk mutiara dan 3 bibit perlubang memberikan pengaruh yang baik terhadap pertumbuhan tanaman padi, yaitu tinggi tanaman dengan nilai $64,37 \mathrm{~cm}$ dan jumlah anakan 38,43 tanaman.

3. Perlakuan pupuk mutiara dan 3 bibit perlubang menghasilkan nilai yang lebih baik dibandingkan perlakuan lainnya.

\section{DAFTAR PUSTAKA}

Abdullah, 2004. Pengaruh perbedaan jumlah dan umur bibit terhadap pertumbuhan dan hasil padi sawah. Prosiding Seminar Nasional Penerapan Agroinovasi Mendukung Ketahanan Pangan dan Agribisnis 8:154-161.

Atman. 2007. Teknologi Budidaya Padi Sawah Varietas Unggul Baru Batang Piaman. Jurnal Ilmiah Tambuah, 6 (1): 58-64 hal.

Badan Pusat Statistik Kabupaten Lamongan (2019). Lamongan Dalam Angka. Lamongan: Bappeda.

Dachban dan Dibisono. 2010. . Pengaruh sistem tanam, varietas jumlah bibit terhadap pertumbuhan dan hasil padi sawah (Oriza sativa L.). Jurnal Ilmiah Pendidikan Tinggi. 3(1): 47-57 hal.

Gardner, F. P. R. B. Peace dan R. Mitchell, 1991. Fisiologi Tanaman Budidaya. Terjemahan Herawati Susilo. UI Press. Jakarta.

Kasim, 2004. Manajemen penggunaan air, meminimalkan penggunaan air untuk meningkatkan produksi padi sawah melalui sistem intensifikasi padi SRI (The System of Rice Intensification). Universitas Andi Djemma, Padang.

Kaya, 2013. Pengaruh Kompos Jerami dan Pupuk NPK Terhadap N-Tersedia Tanah, Serapan-N, Pertumbuhan, dan Hasil Padi Sawah (Oryza sativa L.). 
Prosiding FMIPA Universitas Pattimura 2013 - ISBN: 978-602-97522-0-5. Hal.42. Diakses pada tanggal 22 September 2014.

Koswara, 2009. Teknologi pengolahan beras (teori dan praktek). Ebok pangan.Com.http://tekpan.unimus.ac. id/wpcontent/uploads/2013/07/Tekn ologiPengolahan-Beras-Teori-danPraktek.pdf. Di akses tanggal 2 juni 2015.

Munandar, A 2013, 'Pengaruh komposisi media tanam dan dosis pupuk NPK Mutiara 16:16:16 terhadap pertumbuhan dan hasil tanaman cabai
(Capsicum annum L.)', Desertasi Program Pascasarjana Universitas Syiah Kuala, Banda Aceh.

Sutoro, T. T., Mamik, S., dan Trijatmiko,K. R. 2015.Keragaman Malai Anakandan Hubungannya Dengan Hasil Padi Sawah (Oryza Sativa).Bul. Plasma Nutfah 21 (1) 9-16.

Yitnosumarto, S. 1993. Percobaan, Perancangan, Analisis dan Interprestasinya. Gramedia, Jakarta 